\title{
Hospital-acquired influenza infections detected by a surveillance system over six seasons, from 2010/2011 to 2015/2016
}

P. Godoy ${ }^{1,2,3^{*}}$ D, N. Torner ${ }^{1,2,4}$, N. Soldevila ${ }^{2,4}$, C. Rius ${ }^{2,5}$, M. Jane ${ }^{1,2}$, A. Martínez ${ }^{1,2,4}$, JA. Caylà 2,5 , A. Domínguez ${ }^{2,4}$ and the Working Group on the Surveillance of Severe Influenza Hospitalized Cases in Catalonia

\begin{abstract}
Background: In addition to outbreaks of nosocomial influenza, sporadic nosocomial influenza infections also occur but are generally not reported in the literature.

This study aimed to determine the epidemiologic characteristics of cases of nosocomial influenza compared with the remaining severe cases of severe influenza in acute hospitals in Catalonia (Spain) which were identified by surveillance.

Methods: An observational case-case epidemiological study was carried out in patients aged $\geq 18$ years from Catalan 12 hospitals between 2010 and 2016. For each laboratory-confirmed influenza case (nosocomial or not) we collected demographic, virological and clinical characteristics. We defined patients with nosocomial influenza as those admitted to a hospital for a reason other than acute respiratory infection in whom ILI symptoms developed $\geq 48 \mathrm{~h}$ after admission and influenza virus infection was confirmed using RT-PCR. Mixed-effects regression was used to estimate the crude and adjusted OR.
\end{abstract}

Results: One thousand seven hundred twenty-two hospitalized patients with severe laboratory-confirmed influenza virus infection were included: 96 (5.6\%) were classified as nosocomial influenza and more frequently had $>14$ days of hospital stay $(42.7 \%$ vs. $27.7 \%, P<.001)$ and higher mortality $(18.8 \%$ vs. $12.6 \%, P<.02)$. The variables associated with nosocomial influenza cases in acute-care hospital settings were chronic renal disease (aOR $2.4495 \% \mathrm{Cl} 1.44-$ 4.15) and immunodeficiency (aOR $1.7995 \% \mathrm{Cl} 1.04-3.06)$.

Conclusions: Nosocomial infections are a recurring problem associated with high rates of chronic diseases and death. These findings underline the need for adherence to infection control guidelines.

Keywords: Healthcare-associated infection, Hospitalized patients, Influenza, Nosocomial infection

\section{Background}

Each year, $5-20 \%$ of the population are infected by the influenza virus [1]. Among adults aged $\geq 65$ years and patients with underlying chronic diseases influenza is a leading cause of severe illness and death. Sentinel surveillance of patients hospitalized due to severe laboratory-confirmed influenza is critical to control the

\footnotetext{
* Correspondence: pere.godoy@gencat.cat

${ }^{1}$ Epidemiology Service. Agència de Salut Pública de Catalunya, Generalitat de Catalunya, Barcelona, Spain

${ }^{2}$ CIBER de Epidemiología y Salud Pública (CIBERESP), Barcelona, Spain

Full list of author information is available at the end of the article
}

timing and spread of influenza and detect variations in circulating influenza viruses [2,3].

The Department of Health of Catalonia (Spain) introduced the surveillance of patients hospitalized with laboratory-confirmed influenza to supplement the information provided by the influenza sentinel surveillance system, based on primary healthcare physicians, in October 2010 [4]. During periods of increased influenza activity in the community and the subsequent increase in the number of patients with influenza in hospitals, the risk of nosocomial transmission from infected patients increases [5].

(c) The Author(s). 2020 Open Access This article is distributed under the terms of the Creative Commons Attribution 4.0 International License (http://creativecommons.org/licenses/by/4.0/), which permits unrestricted use, distribution, and reproduction in any medium, provided you give appropriate credit to the original author(s) and the source, provide a link to the Creative Commons license, and indicate if changes were made. The Creative Commons Public Domain Dedication waiver (http://creativecommons.org/publicdomain/zero/1.0/) applies to the data made available in this article, unless otherwise stated. 
Nosocomial influenza is a recognized public health problem in acute-care hospital settings [5] and has been associated with significant morbidity, mortality and high economic costs due to longer hospital stays. It is likely to be under-recognized due to rapid patient turnover and delays in diagnosis.

Outbreaks of influenza have been reported in different hospital wards [6-11]. In addition, sporadic nosocomial influenza infections may occur but are generally not identified or reported [5].

This study aimed to determine the epidemiologic characteristics of nosocomial influenza cases in acute-care hospital settings in Catalonia (Spain) identified by surveillance rather than through outbreak control activity during six consecutive influenza seasons (2010-2011 to 2015-2016).

\section{Methods}

\section{Epidemiological study}

The general methods of this study have been published elsewhere $[12,13]$. In summary, we conducted an observational case-case epidemiological study of the characteristics and risk factors of nosocomial influenza cases in patients hospitalized due to laboratory-confirmed influenza in acute-care hospital settings.

Catalonia (Spain) initiated, in 2010, the surveillance of patients hospitalized due to laboratory-confirmed influenza. The system included a catchment area of 4,644, 543 persons. During each influenza season, the 12 hospitals included in the surveillance system report on patients hospitalized with severe laboratory-confirmed influenza admitted to one of these hospitals.

\section{Study population and data collected}

The study population was reported cases aged $\geq 18$ years hospitalized with severe laboratory-confirmed influenza virus infection during six influenza seasons (2010-2011 to 2015-2016). We included patients hospitalized $\geq 24 \mathrm{~h}$ in any participating hospitals who presented an influenza-like-illness (ILI). A sentinel physician who screened all patients with severe ILI enlisted patients in each participating hospital. All patients had a nasopharyngeal or throat swab (bronchoalveolar lavage fluid or tracheal aspirate for intensive care unit (ICU) patients) and influenza virus infection was detected using reverse transcription polymerase chain reaction (RT-PCR).

From this source of acute-care hospital influenza patients, we defined patients with nosocomial influenza as those admitted to a hospital for a reason other than acute respiratory infection in whom ILI symptoms developed $\geq 48 \mathrm{~h}$ after admission and influenza virus infection was confirmed using RT-PCR.

A structured questionnaire was used by public health officers to collect data from each reported case by interview and review of medical records. This included sociodemographic data, obesity (body mass index $[\mathrm{BMI}]>40$ ), pregnancy, major chronic conditions (chronic obstructive pulmonary disease [COPD]), diabetes, chronic renal disease, immunodeficiency (HIV infection or other), chronic cardiovascular disease, and chronic liver disease).

\section{Laboratory data}

Patient samples were first tested in the laboratories of the participating hospitals using an in-house real-time RT-PCR for influenza A and B after manual nucleic acid extraction. Samples with unsubtyped influenza virus were sent to the Catalan Influenza Reference Laboratory to determine the subtype. Molecular subtyping was used to determine the $\mathrm{H}$ subtype for influenza A and the lineage for influenza B. Subtyping failed in some cases due to a low viral load and such samples were classified as "unidentifiable".

\section{Statistical analysis}

We compared the baseline characteristics of nosocomial influenza cases with those of other hospitalized cases of severe influenza. The baseline variables considered were: sex, age (18-64, 65-74 and $\geq 75$ years), virus type, major chronic conditions (COPD, diabetes, obesity [BMI > 40], chronic renal disease, immunodeficiency [HIV infection or other]), chronic cardiovascular disease, and chronic liver disease), complications, hospital stay, seasonal influenza, and antiviral treatment. The chi-square test and Fisher's exact test were used for categorical variables and the median test for continuous variables.

The length of stay was calculated as from the first day of hospital admission in patients with communityacquired influenza and from the onset of influenza symptoms in patients with nosocomial influenza. To assess the relationships between the dependent variable (nosocomial influenza cases $\mathrm{Yes} / \mathrm{No}$ ) and the independent variables studied, a case-case bivariate analysis was made. Possible interactions between independent variables were analyzed by logistic regression. Independent variables were checked for collinearity using the variance inflation factor. Because there were differences between hospitals in nosocomial influenza cases, a mixed-effects logistic regression model with the variable hospital as a random intercept was constructed to estimate the crude and adjusted odds ratios (OR) and their corresponding 95\% confidence intervals (CI). A multivariate analysis was performed using the mixed-effects logistic regression model that included the variables described. The final model was selected using the backward procedure, with a cut-off point of $p<0.2$.

\section{Ethics approval and consent to participate}

As this study was undertaken as part of a national surveillance system, ethical approval was not required [14]. 


\section{Results}

A total of 1722 patients aged $\geq 18$ years hospitalized with laboratory-confirmed influenza were recorded: 805 (46.7\%) were aged 18-64 years and 917 (53.3\%) $\geq 65$ years and $743(43.1 \%)$ were female. During the six seasons studied, $1480(85.9 \%)$ patients were infected with influenza $A$ viruses $\left(572 \mathrm{H}_{1} \mathrm{~N}_{1}\right.$ and $\left.331 \mathrm{H}_{3} \mathrm{~N}_{2}\right)$ and 241 (14\%) with influenza B viruses.

Of the 1722 patients, 96 (5.6\%) were admitted to a hospital for a reason other than acute respiratory infection and developed ILI symptoms $\geq 48 \mathrm{~h}$ after admission and were classified as nosocomial influenza. Of these 96 cases, 35 (36.5\%) were aged 18-64 years, 22 (22.9\%) were aged $64-74$ years, $39(40.6 \%) \geq 75$ years and $43(44.8 \%)$ were female. Eighty $(83.3 \%)$ patients presented $\geq 1$ influenza risk factor and $36(37.5 \%)$ had received the influenza vaccine (Table 1 ).

There were differences between nosocomial influenza patients and those who were not. Nosocomial influenza cases had a higher frequency of age $65-74$ years $(22.9 \%$ vs. $18.8 \%, P<.13)$, and $\geq 75$ years $(40.6 \%$ vs. $33.9 \%$, $P<.15)$, diabetes ( $35.4 \%$ vs. $24.4 \%, P=.02)$, chronic renal disease $(29.2 \%$ vs. $12.8 \% P<.001)$, immunodeficiency $(28.1 \%$ vs. $18.9 \% P<.001)$, chronic cardiovascular disease (39.6\% vs. $28.8 \% P<.02)$ and chronic liver disease $(8.3 \%$ vs. $6.4 \% P=.25)$. Influenza vaccination uptake was higher in nosocomial influenza patients $(37.5 \%$ vs. $25.6 \%$, $P=.03$ ) (Table 1).

Likewise, nosocomial influenza patients more frequently received antiviral treatment within $48 \mathrm{~h}$ of symptom onset $(67.4 \%$ vs. $23.9 \%, P=.01)$ and had a lower frequency of pneumonia $(54.2 \%$ vs. $76.4 \%, P<.001)$. However, nosocomial influenza patients required more days of hospital stay (median: 13 (2-76) vs. 9 (0-137), $P=.001)$ and a higher mortality rate was observed (18.8\% vs. $12.6 \%, P<.02$ ) (Table 2$)$. No interaction was found between the variables investigated, and there was no collinearity between the variables.

In the multivariable regression model, the variables associated with nosocomial influenza cases were chronic renal disease (aOR 2.44 95\% CI 1.44-4.15) and immunodeficiency (aOR 1.79 95\% CI 1.04-3.06) (Table 3).

Nosocomial influenza cases were a risk factor for death (OR 1.86 95\% CI 1.07-3.23). Furthermore, in the multivariable regression model the risk of death was slightly higher (aOR 3.26 95\% CI 1.53-6.92) after adjustment for the other variables in the model (Table 4).

\section{Discussion}

This study, based on the surveillance of hospitalized cases of severe laboratory-confirmed influenza, shows that $5.65 \%$ of influenza cases in acute hospitals were due to nosocomial transmission and were associated with chronic diseases and a high risk of death. The results highlight the importance of the nosocomial transmission of influenza in acute hospitals in a study with a multicenter design, a large number of patients and an extended study period of six consecutive influenza seasons.

Our results are consistent with other studies that show sporadic nosocomial cases of influenza are a public health problem in acute-care hospital settings. Enstone et al. in the United Kingdom detected 30 nosocomial cases $(2.0 \%)$ in 1520 hospitalized patients with influenza from 75 hospitals [15]; Macesic et al. in Australia recorded 26 nosocomial cases (4.3\%) in 598 hospitalized patients with influenza from 15 hospitals [16]; and Álvarez-Lerma et al in Spain documented 224 nosocomial cases (9.3\%) in 2421 hospitalized patients with influenza from 148 intensive care units [17]. Patients with hospital-acquired influenza infection had a profile that differed from that of patients with community-acquired infections; they were older, more likely to have chronic diseases (diabetes, chronic renal disease, immunodeficiency and chronic cardiovascular disease) and had higher mortality (18.8\%). Similarly, other studies present poor outcomes. While the mortality of nosocomial cases in the study by Enstone et. al was 26.7\% [15], in the study by Álvarez-Lerma et al. it was 39.2\% [17]; in both studies mortality was notably higher than that due to community-acquired influenza [15, 17]. Compared with community-acquired influenza cases, we found a significantly longer stay in patients with nosocomial influenza. Nosocomial influenza has previously been associated with longer hospitalization as well as increased use of diagnostic resources and treatments [5].

Even though vaccination rates were very low in patients with both hospital-acquired and communityacquired influenza virus infection, a higher proportion of nosocomial influenza patients had been vaccinated. This has been observed in other studies [15-17] and may be related to the greater number of comorbidities (COPD, diabetes, chronic renal disease, immunodeficiency and chronic cardiovascular disease) for which vaccination is recommended [18].

As with nosocomial influenza outbreaks $[19,20]$, sporadic nosocomial cases of influenza detected by surveillance during the influenza season may have special interest, as they could suggest failures in hospital infection control. The case series in this study was detected in settings where clinical management and infection control precautions were determined by guidelines [21], and with data recorded by experienced public health staff [4].

There is no standardized definition of nosocomial influenza infection. The mean hospital stay before symptom onset in this study was 14.3 days and we applied a cutoff point of $\geq 2$ days after admission in nosocomial cases. This case definition was based on a review of 
Table 1 Demographic characteristics and comorbidities of patients with community-acquired or nosocomial influenza, Catalonia (Spain)

\begin{tabular}{|c|c|c|c|c|}
\hline Variables & $\begin{array}{l}\text { Hospital acquired } \\
(N=96)\end{array}$ & $\begin{array}{l}\text { Community acquired } \\
(N=1626)\end{array}$ & $\begin{array}{l}\text { Crude OR } \\
(95 \% \mathrm{Cl})\end{array}$ & $P$ value \\
\hline \multicolumn{5}{|l|}{ Age } \\
\hline $18-64$ & 35 (36.5\%) & 770 (47.4\%) & Ref. & \\
\hline $65-74$ & $22(22.9 \%)$ & 305 (18.8\%) & $1.53(0.88-2.66)$ & 0.13 \\
\hline$>=75$ & 39 (40.6\%) & $551(33.9 \%)$ & $1.42(0.88-2.29)$ & 0.15 \\
\hline \multicolumn{5}{|l|}{ Sex } \\
\hline Female & $43(44.8 \%)$ & 700 (43.1\%) & $1.07(0.70-1.62)$ & 0.75 \\
\hline Male & $53(55.2 \%)$ & $926(56.9 \%)$ & Ref. & \\
\hline \multicolumn{5}{|l|}{ COPD } \\
\hline Yes & $26(27.1 \%)$ & $414(25.5 \%)$ & $1.06(0.68-1.70)$ & 0.79 \\
\hline No & $70(72.9 \%)$ & $1212(74.5 \%)$ & Ref. & \\
\hline \multicolumn{5}{|l|}{ Obesity } \\
\hline Yes & $14(14.6 \%)$ & $168(10.3 \%)$ & $1.29(0.71-2.35)$ & 0.41 \\
\hline No & 82 (85.4\%) & 1458 (89.7\%) & Ref. & \\
\hline \multicolumn{5}{|l|}{ Diabetes } \\
\hline Yes & 34 (35.4\%) & 396 (24.4\%) & $1.66(1.07-2.57)$ & 0.02 \\
\hline No & $62(64.6 \%)$ & $1230(75.6 \%)$ & Ref. & \\
\hline \multicolumn{5}{|c|}{ Chronic renal disease } \\
\hline Yes & $28(29.2 \%)$ & $208(12.8 \%)$ & 3.05 (1.89-4.92) & $<0.001$ \\
\hline No & $68(70.8 \%)$ & 1418 (87.2\%) & Ref. & \\
\hline \multicolumn{5}{|c|}{ Immunodeficiency } \\
\hline Yes & $27(28.1 \%)$ & 307 (18.9\%) & $1.96(1.21-3.17)$ & 0.01 \\
\hline No & $69(71.9 \%)$ & 1319 (81.1\%) & Ref. & \\
\hline \multicolumn{5}{|c|}{ Heart disease } \\
\hline Yes & 38 (39.6\%) & $469(28.8 \%)$ & $1.67(1.09-2.57)$ & 0.02 \\
\hline No & $58(60.4 \%)$ & 1157 (71.2\%) & Ref. & \\
\hline \multicolumn{5}{|c|}{ Liver disease } \\
\hline Yes & $8(8.3 \%)$ & $1034(6.4 \%)$ & $1.57(0.73-3.37)$ & 0.25 \\
\hline No & $88(91.7 \%)$ & $1522(93.6 \%)$ & Ref. & \\
\hline \multicolumn{5}{|l|}{ Virus type } \\
\hline A & 79 (82.3\%) & 1401 (86.1\%) & Ref. & \\
\hline B & $17(17.7 \%)$ & $224(13.8 \%)$ & $1.49(0.86-2.59)$ & 0.15 \\
\hline C & $0(0.0 \%)$ & $1(0.1 \%)$ & - & - \\
\hline \multicolumn{5}{|c|}{ Seasonal influenza vaccination } \\
\hline Yes & $36(37.5 \%)$ & $412(25.6 \%)$ & $1.62(1.05-2.52)$ & 0.03 \\
\hline No & $60(62.5 \%)$ & $1198(74.4 \%)$ & Ref. & \\
\hline
\end{tabular}

OR Odds ratio, Cl Confidence interval

health care-associated influenza that showed a median threshold delay between admission and symptom onset of $48 \mathrm{~h}$ (range: 24-96h) [22, 23], suggesting that the erroneous inclusion of community cases of influenza as nosocomial cases is quite improbable. Nevertheless, a standardized definition is lacking, and this should be resolved in the future.
Health care-associated influenza cases could signal failures in hospital infection control, as transmission may have been due to an infectious health care worker [24] or to the contaminated hands of a health care worker [5]. However, infection by other patients could also have occurred. Munier-Marion et al. reported that hospitalizations in double-occupancy rooms are an 
Table 2 Antiviral treatment, complications and risk of death in patients with community-acquired and nosocomial influenza,

\begin{tabular}{|c|c|c|c|c|}
\hline Variables & $\begin{array}{l}\text { Hospital acquired } \\
(N=96)\end{array}$ & $\begin{array}{l}\text { Community acquired } \\
(N=1626)\end{array}$ & $\begin{array}{l}\text { Crude OR } \\
(95 \% \mathrm{Cl})\end{array}$ & $P$ value \\
\hline \multicolumn{5}{|l|}{ Antiviral treatment } \\
\hline Yes & $89(92.7 \%)$ & 1485 (91.3\%) & $1.06(0.48-2.34)$ & 0.89 \\
\hline No & $7(7.3 \%)$ & $141(8.7 \%)$ & Ref. & \\
\hline \multicolumn{5}{|l|}{ Antiviral treatment } \\
\hline$\leq 48 \mathrm{~h}$ before symptom onset & $62(67.4 \%)$ & 375 (23.9\%) & $2.94(1.30-6.66)$ & 0.01 \\
\hline$>48 \mathrm{~h}$ before symptom onset & $23(25.0 \%)$ & $1051(67.1 \%)$ & $0.42(0.18-1.00)$ & 0.05 \\
\hline No & $7(7.6 \%)$ & $141(9.0 \%)$ & Ref. & \\
\hline Hospital stay; median (range) & $13(2-76)$ & $9(0-137)$ & & 0.001 \\
\hline \multicolumn{5}{|l|}{ Hospital stay } \\
\hline 0-14 days & $55(57.3 \%)$ & $1174(72.3 \%)$ & Ref. & \\
\hline$>14$ days & $41(42.7 \%)$ & $450(27.7 \%)$ & $2.04(1.33-3.14)$ & $<0.001$ \\
\hline \multicolumn{5}{|l|}{ Pneumonia } \\
\hline Yes & $52(54.2 \%)$ & $1237(76.4 \%)$ & $0.34(0.22-0.53)$ & $<0.001$ \\
\hline No & $44(45.8 \%)$ & $383(23.6 \%)$ & Ref. & \\
\hline \multicolumn{5}{|l|}{ ARDS } \\
\hline Yes & $33(34.4 \%)$ & $626(39.3 \%)$ & $0.86(0.52-1.42)$ & 0.57 \\
\hline No & $63(65.6 \%)$ & $965(60.7 \%)$ & Ref. & \\
\hline \multicolumn{5}{|l|}{ Multiorgan failure } \\
\hline Yes & $10(10.6 \%)$ & $166(10.5 \%)$ & $1.10(0.56-2.19)$ & 0.78 \\
\hline No & $84(89.4 \%)$ & 1416 (89.5\%) & Ref. & \\
\hline \multicolumn{5}{|l|}{ ICU admission } \\
\hline Yes & 31 (32.3\%) & 561 (34.5\%) & $1.00(0.64-1.56)$ & 0.99 \\
\hline No & $65(67.7 \%)$ & 1065 (65.5\%) & Ref. & \\
\hline \multicolumn{5}{|l|}{ Death } \\
\hline Yes & $18(18.8 \%)$ & 205 (12.6\%) & $1.91(1.11-3.31)$ & 0.02 \\
\hline No & 78 (81.3\%) & 1421 (87.4\%) & Ref. & \\
\hline
\end{tabular}

ARDS Acute respiratory distress syndrome, ICU Intensive care unit, OR Odds ratio, $\mathrm{Cl}$ Confidence interval

important risk factor for hospital-acquired influenza [25]. Another possibility may be transmission from patients' visitors [5, 25].

Strategies to reduce influenza transmission in health facilities should include different methods. Patients with risk factors should be vaccinated before the start of the influenza season. In addition, all their contacts and health care workers should also be vaccinated. Barrier precautions, compliance with hand hygiene and exclusion of sick workers should also be ensured. The influenza vaccine is recommended and funded for older people and risk groups in most European countries, although its effectiveness is not absolute [18]. Reducing transmission from advising of not working or not visiting hospitals when people are sick and applying barrier precautions has some limitations due to the possibility of influenza transmission before the onset of symptoms or with minimal symptomatology [24]. Nevertheless, together these measures may help reduce the number of acquired-hospital influenza cases. Furthermore, the study suggested a high risk of death in elderly patients with nosocomial influenza with chronic renal disease or immunosuppressive diseases and those with stem cell transplantation or cancer. Health care workers caring for these patients should be vaccinated every season and mandatory vaccination may be considered.

Our study is based on a case-case analysis of patients hospitalized with severe laboratory-confirmed influenza. The strengths of the study include the large number of patients hospitalized for influenza, the multicenter design, the uniform patient screening by hospitals, the diagnostic confirmation of all patients and the extended study period of six consecutive influenza seasons.

However, the study has also limitations. Some patients may have been discharged before the onset of hospitalacquired influenza. Furthermore, some patients may 
Table 3 Multivariate logistic regression model of nosocomial influenza risk factors, Catalonia (Spain)

\begin{tabular}{|c|c|c|}
\hline Variables & Adjusted OR (95\% Cl) & $P$ value \\
\hline \multicolumn{3}{|l|}{ Chronic renal disease } \\
\hline Yes & $2.44(1.44-4.15)$ & $<0.001$ \\
\hline No & Ref. & \\
\hline \multicolumn{3}{|l|}{ Immunodeficiency } \\
\hline Yes & $1.79(1.04-3.06)$ & 0.03 \\
\hline No & Ref. & \\
\hline \multicolumn{3}{|l|}{ Liver disease } \\
\hline Yes & $1.72(0.75-3.96)$ & 0.19 \\
\hline No & Ref. & \\
\hline \multicolumn{3}{|l|}{ Antiviral treatment } \\
\hline$\leq 48 \mathrm{~h}$ before symptom onset & $3.43(1.45-8.12)$ & 0.01 \\
\hline$>48 \mathrm{~h}$ before symptom onset & $0.51(0.21-1.26)$ & 0.15 \\
\hline No & Ref. & \\
\hline \multicolumn{3}{|l|}{ Hospital stay } \\
\hline $0-14$ days & Ref. & \\
\hline$>14$ days & $2.57(1.59-4.16)$ & $<0.001$ \\
\hline \multicolumn{3}{|l|}{ Pneumonia } \\
\hline Yes & $0.42(0.26-0.68)$ & $<0.001$ \\
\hline No & Ref. & \\
\hline \multicolumn{3}{|l|}{ ARDS } \\
\hline Yes & $0.60(0.34-1.05)$ & 0.07 \\
\hline No & Ref. & \\
\hline \multicolumn{3}{|l|}{ Death } \\
\hline Yes & $2.25(1.18-4.26)$ & 0.01 \\
\hline No & Ref. & \\
\hline
\end{tabular}

ARDS Acute respiratory distress syndrome, ICU Intensive care unit, $O R$ Odds ratio, $\mathrm{Cl}$ Confidence interval

have minor symptoms which might not be detected and therefore the real number of nosocomial cases might have been underestimated.

\section{Conclusions}

This study shows that nosocomial transmission is a recurrent problem and the total effect of nosocomial

Table 4 Multivariate logistic analysis of nosocomial influenza as a risk factor for death

\begin{tabular}{|c|c|c|c|c|c|c|}
\hline & $\begin{array}{l}\text { Death } \\
(N=223)\end{array}$ & $\begin{array}{l}\text { No death } \\
(N=1499)\end{array}$ & $\begin{array}{l}\text { Crude } \\
\text { OR } \\
(95 \% \text { Cl) }\end{array}$ & $\begin{array}{l}P \\
\text { value }\end{array}$ & $\begin{array}{l}\text { Adjusted } \\
\text { OR } \\
(95 \% \text { Cl) }\end{array}$ & $P$ value \\
\hline $\begin{array}{l}\text { Hospital } \\
\text { acquired }\end{array}$ & $18(8.1 \%)$ & 78 (5.2\%) & $\begin{array}{l}1.86 \\
(1.07- \\
3.23)\end{array}$ & 0.03 & $\begin{array}{l}3.26 \\
(1.53- \\
6.92)\end{array}$ & 0.002 \\
\hline $\begin{array}{l}\text { Community } \\
\text { acquired }\end{array}$ & $\begin{array}{l}205 \\
(91.9 \%)\end{array}$ & $\begin{array}{l}1421 \\
(94.8 \%)\end{array}$ & Ref. & & Ref. & \\
\hline
\end{tabular}

Adjusted for age, antiviral treatment, pneumonia, multiorgan failure, intensive care unit, renal failure, immunodeficiency and chronic liver disease influenza may be underestimated. These results suggest the need to improve infection control guidelines and the vaccination of health care workers and ensure clinical suspicion of influenza in high risk areas. In addition, people should be recommended not to visit hospitals when they are ill.

\section{Abbreviations}

ARDS: Acute respiratory distress syndrome; BMI: Body mass index; COPD: Chronic obstructive pulmonary disease; ICU: Intensive care unit; ILI: Influenza-like-illness; RT-PCR: Polymerase chain reaction

\section{Acknowledgements}

The Working Group on Surveillance of Severe Influenza Hospitalized Cases in Catalonia is composed of:

Alsedà M, Álvarez J, Arias C, Balañà PJ, Barrabeig I, Camps N, Carol M, Ferràs J, Ferrús G, Follia N, Godoy P, Bach P, Jané M, Martínez A, Minguell S, Parrón I, Plasència E, Sala-Farré MR, Torner N, Torra R, Torres J (Public Health Agency of Catalonia); Caylà J, Gorrindo P, Rius C (Public Health Agency of Barcelona); Marcos MA, Mosquera MDM, Vilella A (H Clínic, Barcelona); Antón A, Pumarola T, Campins M (H Universitari Vall d'Hebrón, Barcelona); García D (H Josep Trueta, Girona); Espejo E (H Terrassa); Freixas N, Riera Garcia M (Mútua Terrassa); Maraver E, Mas D, Perez R, (H Altahia Manresa); Rebull J (H.Verge de la Cinta, Tortosa); Pou J (H Sant Joan de Déu, Espluques); García-Pardo G, Olona M (H Joan XXIII, Tarragona); Barcenilla F, Castellana D (H Arnau de Vilanova, Lleida) Navarro-Rubio G (Consorci Sanitari Parc Taulí, Sabadell); Force LL (H Mataró).

\section{Authors' contributions}

NT, MJ, AM, AD and PG designed the study protocol. JC, CR, NT, MJ, AM and PG organized the logistics. JC, CR, NT, and PG participated in the detection of cases, gathering epidemiological information and taking clinical samples and sending samples to the laboratory. NS, AD and PG conducted the epidemiological and statistical analyses of the study. The authors in The Working Group on Surveillance of Severe Influenza Hospitalized Cases in Catalonia participated in the detection of cases, gathering epidemiological information and taking clinical samples and sending samples to the laboratory. PG made a first draft of the paper and all authors made relevant contributions to successive versions. All authors reviewed and approved the final version of the article.

\section{Funding}

This study was funded by the Program of Surveillance, Prevention and Control of Transmissible Diseases (PREVICET) of CIBER de Epidemiología y Salud Pública (CIBERESP), Instituto de Salud Carlos III, Madrid and the Catalan Agency for the Management of Grants for University Research (AGAUR Grant Number 2017/SGR 1342). The funding body had no influence on the design, collection, analysis and interpretation of data or in the manuscript writing.

\section{Availability of data and materials}

The datasets used and/or analyzed during this study are available from the corresponding author on reasonable request.

Ethics approval and consent to participate

As this study was undertaken as part of a national surveillance system, ethical approval was not required and data collation was covered by existing information governance approvals.

\section{Consent for publication}

Not applicable.

\section{Competing interests \\ The authors declare that they have no competing interests.}

\section{Author details}

${ }^{1}$ Epidemiology Service. Agència de Salut Pública de Catalunya, Generalitat de Catalunya, Barcelona, Spain. ${ }^{2}$ CIBER de Epidemiología y Salud Pública (CIBERESP), Barcelona, Spain. ${ }^{3}$ Institut de Recerca Biomédica de Lleida, IRBLleida, Lleida, Spain. ${ }^{4}$ Departamento de Medicina, Universidad de 
Barcelona, Barcelona, Spain. ${ }^{5}$ Agència de Salut Pública de Barcelona, Barcelona, Spain

Received: 18 November 2018 Accepted: 14 January 2020 Published online: 28 January 2020

\section{References}

1. World Health Organization. Influenza (seasonal). Fact sheet. 2016. Available from: http://www.who.int/mediacentre/factsheets/fs211/en/

2. World Health Organization. Global epidemiological surveillance standards for influenza: World Health Organ; 2013. Available: http://who.int/influenza/ resources/documents/WHO_Epidemiological_Influenza_Surveillance_ Standards_2014.pdf?ua=1

3. Chaves SS, Aragon D, Bennett N, Cooper T, D'Mello T, Farley M, et al. Patients hospitalized with laboratory-confirmed influenza during the 20102011 influenza season: exploring disease severity by virus type and subtype. J Infect Dis. 2013;208(8):1305-14.

4. Torner N, Martínez A, Basile L, Plasencia E, Barrabeig I, Follia N, et al. Vigilància epidemiològica dels casos greus hospitalitzats confirmats de grip. Xarxa sentinella PIDIRAC (Catalunya 2010-2015). Butll Epidemiol Catalunya. 2016;37:234-53 Available from: http://canalsalut.gencat.cat/ca/actualitat/ \|lista_butlletins/salut_publica/butlleti_epidemiologic_de_catalunya/.

5. Salgado CD, Farr BM, Hall KK, Hayden FG. Influenza in the acute hospital setting. Lancet Infect Dis. 2002;2:145-55.

6. Sartor C, Zandotti C, Romain F, Jacomo V, Simon S, Atlan-Gepner C, et al. Disruption of services in an internal medicine unit due to a nosocomial influenza outbreak. Infect Control Hosp Epidemiol. 2002;23(10):615-9.

7. Vu D, Peck AJ, Nichols WG, Varley C, Englund JA, Corey L, et al. Safety and tolerability of oseltamivir prophylaxis in hematopoietic stem cell transplant recipients: a retrospective case-control study. Clin Infect Dis. 2007:45(2):187-93.

8. Schepetiuk S, Papanaoum K, Qiao M. Spread of influenza a virus infection in hospitalised patients with cancer. Aust NZ J Med. 1998;28:475-6.

9. Tsagris V, Nika A, Kyriakou D, Kapetanakis I, Harahousou E, Stripeli F, et al. Influenza A/H1N1/2009 outbreak in a neonatal intensive care unit. J Hosp Infect. 2012;81(1):36-40.

10. Ye M, Jacobs A, Khan MN, Jaipaul J, Oda J, Johnson M, et al. Evaluation of the use of oseltamivir prophylaxis in the control of influenza outbreaks in long-term care facilities in Alberta, Canada: a retrospective provincial database analysis. BMJ Open. 2016;6:e011686.

11. Yousuf HM, Englund J, Couch R, Rolston K, Luna M, Goodrich J, et al. Influenza among hospitalized adults with leukemia. Clin Infect Dis. 1997; 24(6):1095-9.

12. Godoy P, Romero A, Soldevila N, Torner N, Jané M, Martínez A, et al. Influenza vaccine effectiveness in reducing severe outcomes over six influenza seasons, a case-case analysis, Spain, 2010/11 to 2015/16. Euro Surveill. 2018;23(43)

13. Domínguez A, Romero-Tamarit A, Soldevila N, Godoy P, Martínez A, Torne $\mathrm{N}$, et al. Effectiveness of antiviral treatment in preventing death in severe hospitalised influenza cases over six seasons. Epidemiol Infect. 2018;146(7): 799-808.

14. Generalitat de Catalunya. Decret 2013/2015, de 15 de setembre, pel qual es crea la Xarxa de Vigilància Epidemiològica i es regulen els sistemes de notificacio de malalties de declaració obligatòria i els brots epidèmics. DOGC. 2015;6958:1-19.

15. Enstone JE, Myles PR, Openshaw PJM, Gadd EM, Lim WS. Nosocomial pandemic (H1N1) 2009, United Kingdom, 2009-2010. Emerg Infect Dis. 2011;17:592-8.

16. Macesic N, Kotsimbos TC, Kelly PCA. Hospital-acquired influenza in an Australian sentinel surveillance system. Med J Aust. 2013;198:370-2.

17. Alvarez-Lerma F, Marin-Corral J, Vila C, Masclans JR, Loeches IM, Barbadillo S, et al. Characteristics of patients with hospital-acquired influenza A (H1N1)pdm09 virus admitted to the intensive care unit. J Hosp Infect. 2017; 95(2):200-6

18. Mereckiene J, Cotter S, Nicoll A, Lopalco P, Noori T, Weber J, et al. Seasonal influenza immunisation in Europe. Overview of recommendations and vaccination coverage for three seasons: pre-pandemic (2008/09), pandemic (2009/10) and post-pandemic (2010/11). Eurosurveillance. 2014;19(16):20780.

19. Chironna M, Tafuri S, Santoro N, Prato R, Quarto M, Germinario CA. A nosocomial outbreak of 2009 pandemic influenza $A(H 1 N 1)$ in a paediatric oncology ward in Italy, October-November 2009. Eurosurveillance. 2010;15(1).

20. Lalayanni C, Sirigou A, Iskas M, Smias C, Sakellari I, Anagnostopoulos A. Outbreak of novel influenza A (H1N1) in an adult haematology department and haematopoietic cell transplantation unit: clinical presentation and outcome. J Inf Secur. 2010;61:270-2.

21. Abraham MK, Perkins J, Vilke GM, Coyne CJ. Influenza in the emergency department: vaccination, diagnosis, and treatment: clinical practice paper approved by American Academy of Emergency Medicine Clinical Guidelines Committee. J Emerg Med. 2016;50(3):536-42.

22. Munier-Marion E, Benet T, Vanhems P. Definition of healthcare-associated influenza: a review and results from an international survey. Influenza Other Respir Viruses. 2017;11(5):367-71.

23. Lessler J, Reich NG, Brookmeyer R, Perl TM, Nelson KE, Cummings DAT. Incubation periods of acute respiratory viral infections: a systematic review. Lancet Infect Dis. 2009;9(5):291-300.

24. Patrozou E, Mermel LA. Does influenza transmission occur from asymptomatic infection or prior to symptom onset? Public Health Rep. 2009;124(2):193-6.

25. Munier-Marion E, Benet T, Regis C, Lina B, Morfin F, Vanhems P. Hospitalization in double-occupancy rooms and the risk of hospitalacquired influenza: a prospective cohort study. Clin Microbiol Infect. 2016; 22(5):461.e7-9.

\section{Publisher's Note}

Springer Nature remains neutral with regard to jurisdictional claims in published maps and institutional affiliations.
Ready to submit your research? Choose BMC and benefit from:

- fast, convenient online submission

- thorough peer review by experienced researchers in your field

- rapid publication on acceptance

- support for research data, including large and complex data types

- gold Open Access which fosters wider collaboration and increased citations

- maximum visibility for your research: over $100 \mathrm{M}$ website views per year

At $\mathrm{BMC}$, research is always in progress.

Learn more biomedcentral.com/submissions 